\title{
Use of a temperature programmed injector with a packed liner for direct water analysis and on-line reversed phase LC-GC
}

\section{Citation for published version (APA):}

Mol, J. G. J., Janssen, J. G. M., Cramers, C. A., \& Brinkman, U. A. T. (1993). Use of a temperature programmed injector with a packed liner for direct water analysis and on-line reversed phase LC-GC. Journal of High Resolution Chromatography, 16(8), 459-463. https://doi.org/10.1002/jhrc.1240160803

DOI:

10.1002/jhrc. 1240160803

Document status and date:

Published: 01/01/1993

\section{Document Version:}

Publisher's PDF, also known as Version of Record (includes final page, issue and volume numbers)

\section{Please check the document version of this publication:}

- A submitted manuscript is the version of the article upon submission and before peer-review. There can be important differences between the submitted version and the official published version of record. People interested in the research are advised to contact the author for the final version of the publication, or visit the $\mathrm{DOI}$ to the publisher's website.

- The final author version and the galley proof are versions of the publication after peer review.

- The final published version features the final layout of the paper including the volume, issue and page numbers.

Link to publication

\section{General rights}

Copyright and moral rights for the publications made accessible in the public portal are retained by the authors and/or other copyright owners and it is a condition of accessing publications that users recognise and abide by the legal requirements associated with these rights.

- Users may download and print one copy of any publication from the public portal for the purpose of private study or research.

- You may not further distribute the material or use it for any profit-making activity or commercial gain

- You may freely distribute the URL identifying the publication in the public portal.

If the publication is distributed under the terms of Article $25 \mathrm{fa}$ of the Dutch Copyright Act, indicated by the "Taverne" license above, please follow below link for the End User Agreement:

www.tue.nl/taverne

Take down policy

If you believe that this document breaches copyright please contact us at:

openaccess@tue.nl

providing details and we will investigate your claim. 


\title{
Use of a Temperature Programmed Injector with a Packed Liner for Direct Water Analysis and On-Line Reversed Phase LC-GC
}

\author{
Hans G.J. Mol*, Hans-Gerd M. Janssen, and Carel A. Cramers \\ Eindhoven University of Technology, Laboratory of Instrumental Analysis, P.O. box 513, 5600 MB, Eindhoven, The Netherlands \\ Udo A.Th. Brinkman
}

Department of Analytical Chemistry, Free University, De Boelelaan 1083, 1081 HV, Amsterdam, The Netherlands

\author{
Key Words: \\ LC-GC \\ Aqueous samples \\ Large volume injection \\ PTV injector \\ Solid-phase extraction \\ Thermal desorption
}

\begin{abstract}
Summary
A system is described that allows the introduction of large volumes of water samples in capillary GC. Water elimination is carried out in the solvent split mode in a PTV injector with a packed liner. Two ways of separating water and analytes, i.e. evaporative and non-evaporative (solid-phase extraction), are compared. Sampling in the solid-phase extraction mode is favorable both in terms of recovery as well as with regard to sampling time. Quantitative recovery is obtained for priority pollutants ranging in volatility from dimethylphenol to phenanthrene. Losses occur for more volatile compounds, but even for these compounds the repeatability of the recoveries remains acceptable. With the system described here, water samples up to at least $1 \mathrm{ml}$ of water can be directly analyzed. The detection limits are in the sub-ppb range.
\end{abstract}

\section{Introduction}

The possibilities for direct introduction of large volumes of aqueous samples, being either reversed-phase LC fractions or water samples, into capillary GC are limited. In most cases direct injection of large volumes of aqueous solvents is incompatible with retention gap techniques due to the physical and chemical properties of water [1]. For that reason a phase switching, i.e. an on-line transfer of the analytes from the aqueous phase to an organic phase, prior to transfer to the GC system is often necessary [2, 3].

An alternative approach is elimination of the water in a temperature programmable injector (PTV injector). The use of PTV injectors for direct introduction of aqueous solvents followed from early work on sorption-thermal desorption of water samples. Pankow et al. [4] described the off-line sampling of water through a Tenax tube. After water removal the adsorbed analytes were thermally desorbed and introduced into the GC system. Schomburg et al. [5] demonstrated a slightly different approach. Here, water was separated on-line using a pre-column packed with Tenax in a dual oven system. Both approaches can also be carried out in a PTV injector, the Tenax tube being the packed liner of the injector. Two preliminary attempts to realize such a set-up were made only recently. Vreuls et al. [6] used Tenax and $\mathrm{C}_{8-}$ and $\mathrm{C}_{18}$-modified silica as packing materials. Quantitative recoveries were obtained for fatty acid methyl esters (E10E18) from a $500 \mu \mathrm{l}$ aqueous solution using the $\mathrm{C}_{8}$-packing material. Villén et al. [7] evaluated the applicability of an experimental design to the optimization of direct analysis of several test compounds in ethanol/water mixtures (12:88). The introduction rate, being one of the key parameters in large volume injection by PTV in the solvent split mode, was not included in the study.

Grob described the so-called vapor overflow technique performed in a PTV injector [8] or in a conventional split/splitless injector [9]. Here the solvent is introduced at a temperature above the pressurecorrected boiling point of the solvent. The sample constituents are retained in the packing of the liner at a cold spot ( $T \approx$ boiling point of solvent) caused by evaporation of the solvent. However, except for very low boiling solvents (e.g. pentane), the temperature of the cold spot is generally much higher than the initial liner temperature which can be applied during large volume injections by PTV in the solvent split mode (typically between -30 and $50^{\circ} \mathrm{C}$ ). This explains how, when using the PTV (liner packed with Tenax) in the solvent split mode, compounds from $n$-C 10 can be quantitatively retained from $500 \mu$ l of hexane [10], while in case of applying vapor overflow only the $n$-alkanes from $n$-C 20 are quantitatively retained in the Tenax liner [9]. Due to the high boiling point of water the vapor overflow technique is not expected to be very suitable for direct introduction of water samples.

In this work a system is described that allows the introduction of large volumes (up to $1 \mathrm{~m}$ ) of water samples in capillary GC. Water elimination is carried out by using the PTV injector with a Tenax liner in the solvent split mode. Two ways of separating water and analytes in the liner, i.e. evaporative and non-evaporative, are compared. The influence of the introduction flow rate and the initial liner temperature on the drying time and recovery is evaluated. Furthermore the effect of the sample volume is studied. A test mixture containing a number of priority water pollutants, representing a variety of volatilities and chemical functionalities, is used for evaluation of the system.

\section{Experimental}

\subsection{Instrumentation}

A gas chromatograph (model 5890, Hewlett Packard, Avondale, PA, USA) equipped with both flame ionization detection (FID) and thermal conductivity detection (TCD) and provided with an automated cold temperature programmable injection system (PTV injector) (KAS 502, Gerstel, Mülheim a/d Ruhr, Germany) was used. 
For data collection an Omega integration system (Perkin Elmer, Cupertino, CA, USA) was employed. The water samples were injected into the PTV injector by a microprocessor-controlled syringe pump (digisampler, Gerstel) which allowed the introduction of volumes up to $1 \mathrm{ml}$ with a speed between 1 and $2000 \mu \mathrm{l} / \mathrm{min}$.

\subsection{Preparation of Tenax Liner}

The liner (92 $\mathrm{mm} \times 1.3 \mathrm{~mm}$ i.d.) was packed with $16-17 \mathrm{mg}$ of Tenax TA (mesh size 35-60, Chrompack, Bergen op Zoom, the Netherlands) between two plugs of glass wool to keep it in place. The length of the Tenax bed was approximately $5 \mathrm{~cm}$. A dent was made in the liner, $2 \mathrm{~cm}$ from the bottom side, to reduce the amount of glass wool needed to prevent the Tenax from being blown out of the liner. For clean-up the liner was heated to $280^{\circ} \mathrm{C}$ for 48 hours. During this a helium flow of $10 \mathrm{ml} / \mathrm{min}$ was applied. After this the liner was placed in the PTV injector, purged with helium for $15 \mathrm{~min}$ and then heated to $310^{\circ} \mathrm{C}$ for $10 \mathrm{~min}$. After this pretreatment excellent blanks are obtained up to temperatures of $300^{\circ} \mathrm{C}$. Acceptable blanks were obtained up to $325^{\circ} \mathrm{C}$

\subsection{Operating Conditions}

The system is schematically depicted in Figure $\mathbf{1}$ in the configuration during water introduction/elimination. During water sampling the back pressure regulator is by-passed via valve V2 in order to obtain a lower inlet pressure. This enhances evaporation of the solvent. The water is pushed through the liner by the helium purge flow (adjusted to $600 \mathrm{ml} / \mathrm{min}$ ). To prevent water from entering the $\mathrm{GC}$ column the column was cut some $75 \mathrm{~cm}$ from the injector and an additional helium flow was applied $(30 \mathrm{ml} / \mathrm{min})$ via a $\mathrm{T}$ piece (graph pack connections, Gerstel). Vent capillaries between the

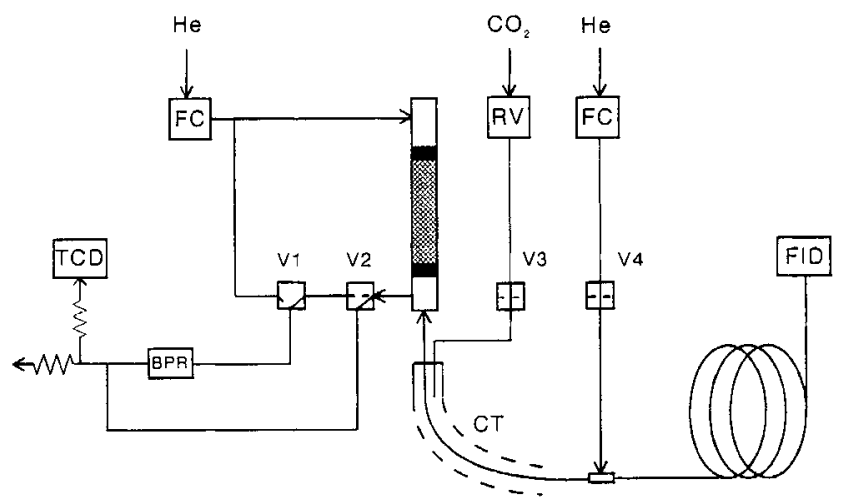

\begin{abstract}
Figure 1
Schematic diagram of PTV-GC system used for direct large volume water introduction. $\mathrm{FC}=$ flow controller, $\mathrm{BPR}=$ back pressure regulator, $\mathrm{RV}=$ reducing valve, $\mathrm{V} 1-\mathrm{V4}=$ valves, $\mathrm{TCD}=$ thermal conductivity detector, $\mathrm{FID}=$ flame ionization detector, CT = cold trap.
\end{abstract}

solvent vent exit and the TCD detector were, as far as they were located outside the oven, heated by heating wire to $80^{\circ} \mathrm{C}$ to prevent condensation of water when drying the liner. After sampling and an additional purge time for complete elimination of water, which could be monitored by the TCD detector, valves V1, V2, and V4 are switched. Now the standard configuration of the GC in the splitless mode is obtained (back-pressure regulated). The compounds are themally desorbed from the Tenax liner by heating the PTV from the initial temperature to $300^{\circ} \mathrm{C}$ (isothermal for $2 \mathrm{~min}$ ) with a rate of $2 \%$. $3.25 \mathrm{~min}$ after starting desorption the split valve V1 is opened. After desorption refocusing of the compounds is necessary to reduce the injection band width. This is done by means of a simple cold trap (DKK Corporation, Tokyo, Japan). By opening valve
V3 (before desorption) the first part of the column is cooled by expanding carbon dioxide flowing through a Tefion tube in which the first part of the column is located. After closing valve V3, 2 min after start of the desorption, the cooled part will be heated rapidly to the GC oven temperature. For GC separation a $25 \mathrm{~m} \times 0.32 \mathrm{~mm}$ i.d. column coated with $0.52 \mu \mathrm{m}$ HP-Ultra-1 was used at an inlet pressure of $110 \mathrm{kPa}$. The GC oven temperature program started at an initial oven temperature of $80^{\circ} \mathrm{C}$ for $2 \mathrm{~min}$, and increased with $10^{\circ} / \mathrm{min}$ to $210^{\circ} \mathrm{C}$ (held for $1 \mathrm{~min}$ ).

\section{Results and Discussion}

In large volume sample introduction performed in a PTV injector the split vent is open during introduction of the sample. The solvent is selectively eliminated via the split vent while (less volatile) compounds are retained in the liner. After an additional purge time for removing the remaining solvent from the liner, the analytes are desorbed and transferred into the GC column in the splitless mode. The optimization of large volume sample introduction by PTV has recently been evaluated [11-13]. Important parameters that have to be taken into account are the design of the liner, the initial liner temperature, the inlet pressure, the purge flow rate through the liner, the sample introduction speed, the additional purge time, the sample volume and the physico-chemical properties of the solvent.

Of all common solvents water is one of the most troublesome in large volume sampling. It not only has adverse evaporation characteristics but it is also chemically aggressive at higher temperatures which can lead to deterioration of the GC column. Moreover, reduction of the losses of volatile analytes in large volume injection with PTV injectors by applying sub-zero initial temperatures is not possible with water. An altemative way to reduce the loss of volatiles, i.e. creation of a solvent film in a porous glass bed inside the liner [13], is also not applicable for water as water does not form a solvent film on a deactivated glass surface. Therefore, in case of water, adsorption materials have to be used in order to prevent losses of the more volatile compounds. It is now, however, inherent to the use of adsorption materials that there will be a restriction in the applicability of the system for high boiling compounds because of the thermal desorption step included in the procedure.

For large volume injections by PTV, in general, the sample introduction rate should not exceed the evaporation rate of the solvent. Introduction flow rates that are too high will lead to flooding of the liner, which means that part of the solvent will be eliminated through the split vent as a liquid (containing sample compounds). This is the situation for sampling of organic solvents. If the solvent is water, solutes can be retained even when flooding of the liner occurs because from water many compounds will adsorb onto the packing material.

As already mentioned before, there are in principle two ways to separate water from the analytes in the liner: evaporative and non-evaporative. The packed liner acts as a GC precolumn or as a solid-phase extraction (SPE) cartridge, respectively. For evaporative sample introduction the sampling rate should not exceed the evaporation rate of the solvent, i.e. the water. From equation (1) the maximum speed of sample introduction can be calculated assuming isothermal evaporation conditions and assuming that the gas leaving the liner is saturated with solvent vapor [12]

$F_{\text {inj, max }}=F_{\text {evap }}=\frac{M p_{j}}{\rho R T_{0}} \frac{p_{0}}{p_{i}} F_{t, 0}$

where $F_{\text {inj,max }}$ is the maximum speed of sample introduction, $F_{\text {evap }}$ the solvent evaporation rate, $F_{t, 0}$ the total gas flow rate at outlet 
conditions ( $T_{0}$ and $p_{0}$ ) and $p_{1}$ the inlet pressure of the liner, $M$ the molecular weight of the solvent, $\rho$ the density of the solvent, $p_{j}$ the partial pressure of the solvent at the initial liner temperature, and $R$ the gas constant. In Figure 2 the influence of the liner temperature on the evaporation rate of water is illustrated for three different purge flow rates. The inlet pressure for the Tenax liner increases with the helium purge flow and the initial liner temperature and varies from $15 \mathrm{kPa}$ to $96 \mathrm{kPa}$ (for $100 \mathrm{ml} / \mathrm{min}, 10^{\circ} \mathrm{C}$ and $600 \mathrm{ml} / \mathrm{min}$. $70^{\circ} \mathrm{C}$, respectively). As can be seen from Figure 2, increasing the helium purge flow leads (although partly offset by the increase of the inlet pressure) to a considerable increase of the evaporation rate. From large volume injections with hexane as the solvent it was seen that increasing the helium purge flow caused some decrease in the recovery of more volatile compounds [10]. However, in order to minimize sample introduction times and, in case of sampling in the SPE mode the time required for drying, a high purge flow of 600

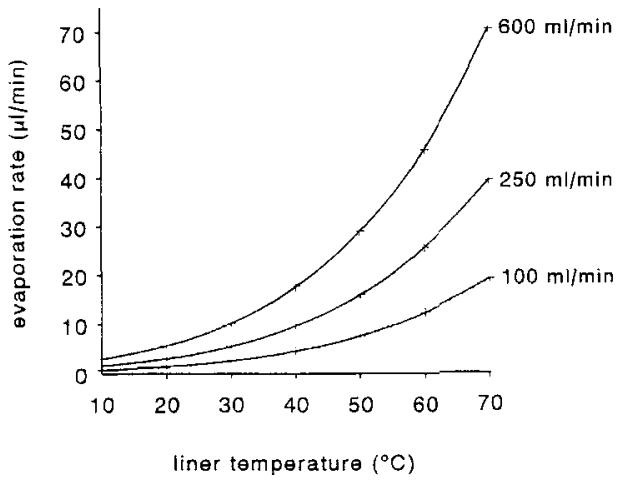

Figure 2

Evaporation rate of water as a function of liner temperature and purge flow rate.

$\mathrm{ml} / \mathrm{min}$ was used throughout this study.

From Figure 2 it is clear that introduction flow rates in the evaporative sampling mode are low, e.g. about $10 \mu \mathrm{l} / \mathrm{min}$ at $30^{\circ} \mathrm{C}$, leading to long sampling times. More rapid sampling can be performed at higher introduction temperatures but then the applicability of the technique will be restricted to higher boiling compounds. Moreover, in practice, the evaporation rates will be lower than plotted in Figure 2 due to cooling of the liner by the evaporation process.

When separating water and analytes in the SPE mode much higher introduction flow rates can be applied. Here, the maximum sampling speed is determined by the experimental set up, the efficiency of the packed bed, the back flow from the column to the liner (required to prevent water entering the $\mathrm{GC}$ column during injection) and the sample volume. In the configuration depicted in Figure 1, a back flow of $30 \mathrm{ml} / \mathrm{min}$ allowed injection speeds up to at least 250 $\mu \mathrm{l} / \mathrm{min}$ for $500 \mu \mathrm{l}$ samples. Lower back flows resulted in the introduction of a small amount of water into the GC column, as could be seen from a small disturbance of the FID signal during introduction (the water contained $0.5-1 \%$ of methanol).

The effect of the sample introduction flow rate on the recovery was determined at $30^{\circ} \mathrm{C}$ and $50^{\circ} \mathrm{C}$ for $250 \mu \mathrm{l}$ samples. At very low flow rates water will evaporate in the top of the liner and volatile analytes have to be trapped from the gas phase. At high flow rates water will be pushed through the liner as a plug of liquid followed by elimination of the remaining water by evaporation. At intermediate flow rates part of the water will evaporate during introduction whereas the remainder will be pushed through the packing as a liquid, probably in the form of droplets rather than as a continuous plug of liquid. More or less 'concurrent solvent evaporation' like-conditions

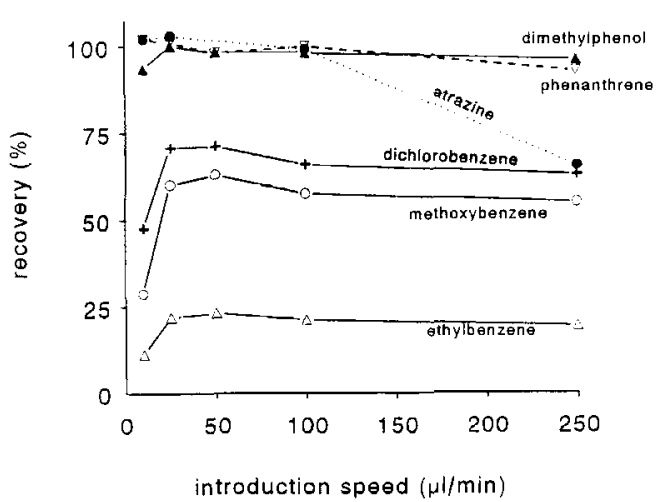

Figure 3

Recovery vs. introduction speed of water samples. PTV initial temperature: $50{ }^{\circ} \mathrm{C}$. Sample volume: $250 \mu \mathrm{l}$.

occur at $50^{\circ} \mathrm{C}$ and an introduction speed of $10 \mu \mathrm{l} / \mathrm{min}$. As can be seen from Figure 3 , this results in lower recoveries for the most volatile compounds compared to sampling at higher flow rates. These low recoveries seem to be mainly due to the long overall introduction time compared to sampling in the SPE mode. For compounds with higher boiling points (e.g. dimethylphenol, b.p. = $203^{\circ} \mathrm{C}$ ) the introduction flow rate does not affect the recovery. An exception in this respect is atrazine. For this compound the recovery decreased with increasing introduction flow rate. Apparently, the affinity of atrazine for Tenax is limited when sampling in the SPE mode. Partial evaporation of the water during introduction improves the recovery of this compound. When using evaporative sampling the recovery is quantitative as atrazine is relatively non-volatile.

After introduction of the water sample the liner has to be purged with helium for an additional time in order to obtain complete elimination of water before transfer of the compounds to the GC column in the splitless mode. The drying of the liner was monitored by splitting part of the purge flow from the solvent vent exit to a TCD detector. The splitless transfer was started at the moment the TCD signal was back on its initial background value. Monitoring the water elimination is very important as the drying times were found to show strong fluctuations. This is most likely due to rearrangement of the packing which is repetitively flooded with water and dried. Drying times for a completely flooded liner were as follows: $10^{\circ} \mathrm{C}=9-18 \mathrm{~min} ; 30^{\circ} \mathrm{C}=6-8.5 \mathrm{~min} ; 50^{\circ} \mathrm{C}=3.5-5 \mathrm{~min}$. Incidentally, drying times were much longer. This is probably due to channel formation in the packing. The additional purge time needed for water elimination was also an indication whether or not, at a given temperature and introduction speed, water evaporated partially during injection. In Table $\mathbf{1}$ average drying times for different introduction flow rates and temperatures are shown.

\section{Table 1}

Additional purge time for complete elimination of water after sampling of $250 \mu \mathrm{l}$ water.

\begin{tabular}{cll}
\hline Introduction flow rate $(\mu \mathrm{l} / \mathrm{min})$ & \multicolumn{2}{c}{ Additional purge time $(\min )$} \\
\cline { 2 - 3 } & $30^{\circ} \mathrm{C}$ & $50^{\circ} \mathrm{C}$ \\
\hline 10 & 3 & 1.75 \\
25 & 8 & 2.25 \\
50 & 7.5 & 3.25 \\
100 & 7.1 & 4.3 \\
250 & 7.1 & 4.3 \\
\hline
\end{tabular}

The back flow from the column to the liner during introduction and water elimination in the PTV injector efficiently prevents water from entering the GC column. Even after ca. 200 injections no deteriora- 
Table 2

Recovery ${ }^{a)}(\operatorname{Rec})$ and repeatability (RSD $\%, n=3$ ) for several initial liner temperatures.

Sample: $250 \mu \mathrm{l} 80 \mathrm{ppb}$ in water, introduction rate $=100 \mu \mathrm{l} / \mathrm{min}$.

\begin{tabular}{|c|c|c|c|c|c|c|c|}
\hline \multirow[b]{2}{*}{ Compound } & \multirow{2}{*}{$\begin{array}{c}\text { B.p. } \\
{ }^{\circ} \mathrm{C}\end{array}$} & \multicolumn{2}{|c|}{$10^{\circ} \mathrm{C}$} & \multicolumn{2}{|c|}{$30^{\circ} \mathrm{C}$} & \multicolumn{2}{|c|}{$50^{\circ} \mathrm{C}$} \\
\hline & & $\mathrm{Rec}$ & $\mathrm{RSD} \%$ & Rec & $\mathrm{RSD} \%$ & Rec & $\overline{\mathrm{RSD}} \%$ \\
\hline 1) toluene & 111 & 24 & 12 & 20 & 3.4 & 3 & - \\
\hline 2) ethylbenzene & 137 & 39 & 4.4 & 36 & 7.9 & 21 & 12 \\
\hline 3) methoxybenzene & 156 & 88 & 3.0 & 80 & 2.0 & 58 & 6.6 \\
\hline 4) p-dichlorobenzene & 174 & 80 & 5.5 & 78 & 2.8 & 66 & 5.0 \\
\hline 5) 2,6-dimethylphenol & 203 & 97 & 1.8 & 101 & 1.4 & 98 & 0.5 \\
\hline 6) 2,6-dimethylaniline & 213 & 94 & 3.0 & 100 & 0.3 & 102 & 2.2 \\
\hline 7) p-chloroaniline & 232 & 88 & 15 & 98 & 4.0 & 85 & 3.5 \\
\hline 8) indole & 253 & 96 & 4.4 & 100 & 0.6 & 102 & 1.5 \\
\hline 9) 2,6-dichlorobenzonitrile & - & 100 & 3.7 & 98 & 1.7 & 101 & 2.8 \\
\hline 10) 2,4,5-trichlorophenol & 248 & 103 & 4.2 & 104 & 3.3 & 105 & 1.1 \\
\hline 11) p-dinitrobenzene & 299 & 97 & 11 & 103 & 2.6 & 102 & 1.0 \\
\hline 12) trifluralin & - & 74 & 18 & 81 & 21 & 65 & 13 \\
\hline 13) atrazine & - & 73 & 14 & 74 & 6.4 & 99 & 9.4 \\
\hline 14) phenanthrene & 340 & 97 & 6.6 & 102 & 3.3 & 100 & 4.1 \\
\hline
\end{tabular}

a) Recovery in \%, reference: cold splitless injection of $1 \mu \mathrm{l}$ of a $20 \mathrm{ppm}$ solution in methylene chloride.

tion in peak shapes were observed for a number of critical test compounds.

The effect of the initial liner temperature on the recovery and repeatability is shown in Table 2 for sampling in the SPE mode. Volatile compounds are best retained on the Tenax liner at $10^{\circ} \mathrm{C}$, although the differences with trapping at $30^{\circ} \mathrm{C}$ are not large. This is possibly due to the longer drying times needed at $10^{\circ} \mathrm{C}$. Quantitative trapping for most compounds with boiling points higher than approximately $200^{\circ} \mathrm{C}$ is obtained at temperatures of $50^{\circ} \mathrm{C}$ or lower. It should be emphasized, however, that retention of the compounds on Tenax is, of course, also affected by their chemical structure. The repeatability (relative standard deviation, RSD of the recoveries) is acceptable (trifluralin being an exception), even for the volatile compounds which are not retained quantitatively.

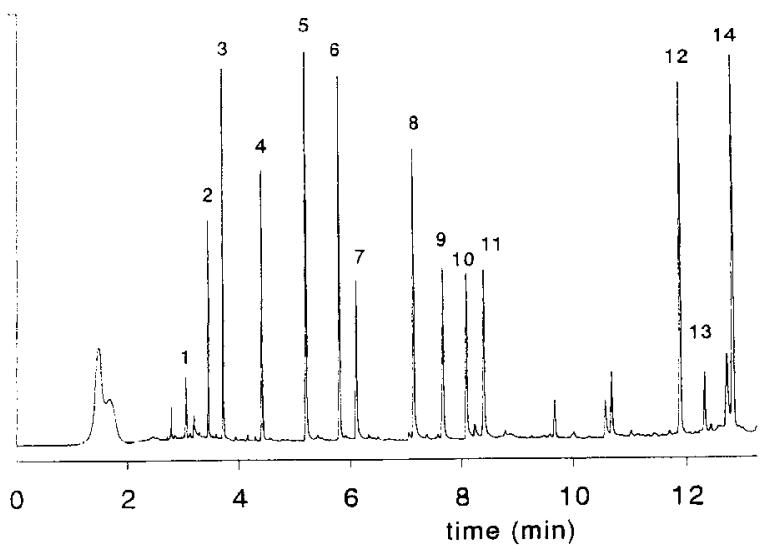

Figure 4

Chromatogram of introduction of $1 \mathrm{mI}$ water sample containing $10 \mathrm{ppb}$ of the compounds given in Table 2. Introduction rate $=100 \mu \mathrm{l} / \mathrm{min}$, PTV initial temperature $=30^{\circ} \mathrm{C}$.

To study the effect of the sample volume on the recovery sample sizes ranging from 25 to $1000 \mu \mathrm{l}$ were introduced at a temperature of $30^{\circ} \mathrm{C}$ and an injection rate of $100 \mu \mathrm{l} / \mathrm{min}$. The recoveries of the most volatile compounds (1 to 4 in Table 2) decreased about 7\% for a $1 \mathrm{ml}$ injection compared to the $250 \mu \mathrm{l}$ injection. Also atrazine showed higher losses for increased sample volumes which confirms the assumption that this compound is poorly retained on Tenax from water. For atrazine the recoveries for sample volumes of 25 , 250 and $1000 \mu \mathrm{l}$ were 88,74 and $62 \%$, respectively. For the other compounds trapping efficiencies of approximately $100 \%$ were obtained up to volumes of $1 \mathrm{ml}$. As an illustration a chromatogram obtained from a $1 \mathrm{ml}$ injection of the test mixture at a $10 \mathrm{ppb}$ level is shown in Figure 4. Even at this very low concentration excellent signal to noise ratios are obtained as is evidenced by the chromatogram in Figure 4. The estimated detection limits of the current set-up are in the sub-ppb range.

The applicability of the system to real-life samples, as well as the use of alternative adsorption materials with higher retention power (for volatile compounds) and less retention power (for expansion of the applicability to higher boiling compounds), and the consequences of introduction of reversed-phase LC eluents (i.e. methanol- or acetonitrile/water mixtures) are currently under investigation.

\section{Conclusions}

The system described in this work allows the direct introduction of large volumes of water samples into capillary $\mathrm{GC}$ by water elimination in a PTV injector containing a liner packed with Tenax. Sampling in the SPE mode is advantageous over evaporative separation of water and analytes, both in terms of recovery and in terms of sampling time. The use of a TCD detector to monitor water elimination from the liner is essential as drying times are not constant. Quantitative recoveries are obtained for compounds with boiling points higher than approximately $200^{\circ} \mathrm{C}$ at introduction temperatures of $30^{\circ} \mathrm{C}$ and $50^{\circ} \mathrm{C}$. More volatile compounds are partially lost, but the repeatability of the recoveries remain at an acceptable level. With the system presented here water samples with volumes up to at least $1 \mathrm{ml}$ can be introduced into capillary GC. This results in detection limits in the sub-ppb range.

\section{Acknowledgment}

The foundation for Chemical Research in the Netherlands (SON) is gratefully acknowledged for their financial support. 


\section{References}

[1] K. Grob, "On-line Coupled LC-GC", Huethig, Heidelberg, 1991.

[2] J.J. Vreuls, V.P. Goudriaan, U.A.Th. Brinkman, and G.J. de Jong, J. High Resolut Chromatogr 14 (1991) 475-480

[3] H.G.J. Mol, J. Staniewski, H.-G. Janssen, C.A. Cramers, R.T. Ghijsen, and U.A.Th Brinkman, J. Chromatogr. 630 (1993) 201-212

[4] J.F. Pankow, L.M. Isabelle, and T.J. Kristensen, Anal. Chem. 54 (1982) 1815-1819.

[5] G. Schomburg, E. Bastian, H. Behlau, H. Husmann, F. Weeke, M. Oreans, and F. Muller, J. High Resolut. Chromatogr. 7 (1984) 4-12.

[6] J.J. Vreuls, U.A.Th Brinkman, G.J. de Jong, K. Grob, and A. Artho, J. High Resolut. Chromatogr 14 (1991) 455-459.
[7] J. Villén, F.J. Señoráns, M. Herraiz, G. Reglero, and J. Tabera, J. Chromatogr. Sci. 30 (1992) 261-266

[8] K. Grob, J. High Resolut. Chromatogr. 13 (1990) 540-546

[9] K. Grob and S. Brem, J. High Resolut. Chromatogr. 15 (1992) 715-722

[10] H.G.J. Mol, H.-G. Janssen, and C.A. Cramers, manuscript in preparation

[11] J. Staniewski and J.A. Rijks, in P. Sandra (Editor). Proceedings of the 13th Symposium on Capillary Chromatography, Riva del Garda, Italy, 1991, Huethig, Heidelberg, 1991, pp. 1334-1347.

[12] J. Staniewski and J.A. Rijks, J. Chromatogr. 623 (1992) 105-113.

[13] J. Staniewski and J.A. Rijks, J. High Resolut. Chromatogr. 16 (1993) 182-187.

Ms received: May 28, 1993 Accepted: July 22, 1993 